\title{
SMALL NON-FLYING MAMMALS FROM CONSERVED AND ALTERED AREAS OF ATLANTIC FOREST AND CERRADO: COMMENTS ON THEIR POTENTIAL USE FOR MONITORING ENVIRONMENT
}

\author{
BONVICINO, C. R., ${ }^{1,2}$ LINDBERGH, S. M. ${ }^{3}$ and MAROJA, L. S. ${ }^{1,2}$ \\ 'Divisão de Genética, Coordenação de Pesquisa, INCa, Praça da Cruz Vermelha, 23, 6o andar, \\ CEP 20230-130, Rio de Janeiro, Brazil \\ ${ }^{2}$ Departamento de Medicina Tropical, IOC-FIOCRUZ, Rio de Janeiro, Brazil \\ ${ }^{3}$ SQS 309, bloco K, ap. 106, CEP 70362-110, Brasília, DF, Brazil \\ Correspondence to: Cibele Rodrigues Bonvicino, Divisão de Genética, Coordenação de Pesquisa, INCa, \\ Praça da Cruz Vermelha, 23, 6º andar, CEP 20230-130, Rio de Janeiro, Brazil, e-mail: cibelerb@inca.gov.br \\ Received August 28, 2001 - Accepted January 10, 2002 - Distributed November 30, 2002
}

(With 1 figure)

\begin{abstract}
Two Atlantic Forests and two Cerrado areas in Brazil were sampled for non-flying small mammal fauna. In each biome one area with altered and another with almost unaltered vegetation (national parks), were chosen to investigate these fauna. Species richness of Atlantic Forest and Cerrado was comparable in the conserved as well as in the altered areas. Data suggested that species could be divided into different ecological categories according to distribution, use of altered and/or relatively unaltered vegetation and habitat specificity. Within these ecological categories some species are appropriate indicators for monitoring environmental quality and degradation. Useful guidelines for wildlife management planning, including selecting areas for conservation units and their better boundary delimitation can ensue.
\end{abstract}

Key words: Brazil, Cerrado, Atlantic Forest, small rodents, marsupials.

\section{RESUMO}

Pequenos mamíferos não voadores de áreas conservadas e alteradas da Floresta Atlântica e do Cerrado: comentários sobre seu uso potencial no monitoramento ambiental

A fauna de pequenos mamíferos não voadores foi amostrada em duas áreas localizadas na Floresta Atlântica e duas no Cerrado, no Brasil. Em cada bioma foram escolhidas uma área alterada e outra com vegetação pouco alterada (parques nacionais) para investigar essa fauna. A riqueza de espécies da Floresta Atlântica e do Cerrado foi comparável nas áreas com vegetação conservada e nas áreas com vegetação pouco alterada. Os dados sugerem que as espécies podem ser divididas em diferentes categorias ecológicas de acordo com sua distribuição, uso da vegetação alterada e/ou pouco alterada e especificidade do habitat. Dentro dessas categorias ecológicas algumas espécies são indicadores apropriados para monitorar a qualidade e degradação ambiental. Conseqüentemente, são ferramentas úteis para o planejamento do manejo da vida silvestre, incluindo seleção de áreas para unidades de conservação e delimitação mais adequada.

Palavras-chave: Brasil, Cerrado, Floresta Atlântica, pequenos roedores, marsupiais. 


\section{INTRODUCTION}

The distribution of mammals, especially endangered species, has been used to justify the establishment of new conservation units. In Brazil, primates have received most of the attention. Several Brazilian conservation units, e.g. Poço das Antas Biological Reserve (Rio de Janeiro State, Golden Lion-tamarin), Una Biological Reserve (Bahia State, Gold and Black Lion-tamarin), Sauim Castanheiras Ecological Reserve (Amazonas State, Pied Bare-Face tamarin) have been established to protect the endangered primate species. The conservation of biological diversity may not be accomplished if the reserves are always based on hierarchically selected flagship mammal species, although this approach will be difficult to change.

Recent works revealed the great diversity and endemicity of the small mammal fauna suggesting that this group can be used in environmental studies. The endemicity of small mammals is documented not only for the Atlantic Forest (Voss, 1993; Hershkovitz, 1998; Weksler et al., 1999) but also for the Cerrado biome (Gomes, 1991; Hershkovitz, 1990, 1993, 1994; Palma \& Yates, 1998; Bonvicino et al., 1998, 1999) and the Cerrado and Caatinga biomes (Moojen et al., 1997; Bonvicino \& Weksler, 1998). The controversy regarding the taxonomy of Brazilian small mammals and the following difficulty for a correct identification of the species have been commented in conservation studies (Marinho-Filho et al., 1994). Fortunately, due to the increase in multidisciplinary works, using geographic, ecological, morphologic and genetic data (Carleton \& Musser, 1989; Voss, 1993; Bonvicino \& Weksler, 1998; Bonvicino et al., 1998; Musser et al., 1998) a more detailed description of taxa with comparisons among similar species is ensuing.

The aim of this work was to investigate the small non-flying mammals in Atlantic Forest and Cerrado localities in order to compare the altered and conserved areas. Based on these results we comment on the use of these species as tools for monitoring conservation units and as indicators of biodiversity.

\section{MATERIAL AND METHODS}

Sampling took place in two Brazilian biomes, Atlantic Forest and Cerrado. The tropical Atlantic Forest areas are Caparaó National Park (PNC, $20^{\circ} 19^{\prime}$ to $20^{\circ} 37^{\prime} \mathrm{S}, 41^{\circ} 43^{\prime}$ to $\left.41^{\circ} 53^{\prime} \mathrm{W}\right)$, Minas Gerais and Espírito Santo states, and Pedreira (PD, 2243'S, 4655'W), São Paulo State. The Cerrado areas are Chapada dos Veadeiros National Park (PNCV, $13^{\circ} 51^{\prime}$ to $14^{\circ} 10^{\prime} \mathrm{S}, 4^{\circ} 25^{\prime}$ to $47^{\circ} 42^{\prime} \mathrm{W}$ ) and Terezina de Goiás (TZ, $13^{\circ} 31^{\prime}$ to $13^{\circ} 34^{\prime} \mathrm{S}, 4^{\circ} 09^{\prime}$ to $47^{\circ} 12^{\prime} \mathrm{W}$ ), both in the Goiás State. High altitude (but with considerable variation) and rich physiognomic mosaics characterise both protected areas. The two sampled areas with altered vegetation had no altitude variations. Trap-nights totalled 9166, of which 3231 were in PNC, 1830 in PD, 2665 in PNCV, and 1440 in TZ (see Tables 1 and 2 for details). Sherman and Tomahawk traps were spaced at approximately every 10 meters to form linear ground transects. The bait was a mixture of bacon, peanut butter, oatmeal and banana and, for the Tomahawk traps, the bait was spread on a manioc slices.

In PNC the sampled areas varied between 970 and $2700 \mathrm{~m}$ altitude. The vegetation sampled included: mountain field (MF, humid or dry grassland), humid mountain forest (HM, evergreen trees in permanent stream valleys), mountain scrub (MS, small trees with twisted trunks), primary (PF) and secondary forest (SF) both humid evergreen forest, vestigial forest (AP, small wood lots and isolated trees of sub mountain or lowland forest resulting from anthropic interventions). Although these physiognomies are nowadays protected, some of them are still going through a process of recuperation. In PNCV sampled areas varied between 650 and $1500 \mathrm{~m}$ of altitude. The vegetation sampled included "campo úmido" (CU, wet grasslands), "vereda" (VE, wet grasslands with buriti palm), "cerrado sensu stricto" (CE, open canopy wooded savannah), "campo cerrado" (CC, scarce wooded savannah), "cerrado rupestre" (CR, open wooded savannah with rocky outcrops), gallery forest (GF) and hillside forest (HF).

In TZ sampled areas varied from 390 to 500 $\mathrm{m}$. The vegetation included gallery Forest (GF), semi deciduous forest (SD), "cerrado sensu stricto" (CE), "vereda" (VE) and sugar cane plantation (AP). All of these vegetation types are altered, except VE. In PD sampled areas were ca. $400 \mathrm{~m}$ in altitude and included secondary Atlantic forest (SF, in different stages of degradation), very disturbed vegetation (CA, very altered early growth forest vegetation), planted pasture (AP), eucalyptus plantation with native undergrowth (EU). 
TABLE 1

Small mammals from the Caparaó National Park (PNC), Chapada dos Veadeiros National Park (PNCV), Terezina de Goiás (TZ), Pedreira (PD). Numbers refer to captured specimens, (av) to observed specimens, (-) to absent, $(*)$ to Cerrado endemic species, (+) to Atlantic Forest endemic species, and 2n to chromosome diploid number.

\begin{tabular}{|c|c|c|c|c|c|c|c|}
\hline Taxa & PNC & PD & PNCV & $\mathbf{T Z}$ & $\mathbf{T}$ & $2 n$ & $\begin{array}{c}\text { Voucher } \\
\text { specimens }\end{array}$ \\
\hline \multicolumn{8}{|l|}{ RODENTIA } \\
\hline Rattus rattus & - & 3 & - & 3 & 6 & 38 & \\
\hline Akodon cursor & 48 & - & - & - & 48 & 14 & MN32049 \\
\hline Akodon montensis & - & 30 & - & - & 30 & 24 & MN46827 \\
\hline Akodon serrensis + & 83 & - & - & - & 83 & 46 & MN32115 \\
\hline Akodon mystax + & 17 & - & - & - & 17 & 44 & MN31904 \\
\hline Thaptomys nigrita + & 14 & - & - & - & 14 & 52 & MN32172 \\
\hline Bolomys lasiurus & - & 24 & 23 & 1 & 48 & 34 & MN43024 \\
\hline Brucepattersonius griserufescens + & 18 & - & - & - & 18 & 52 & MN32013 \\
\hline Oxymycterus caparaoe + & 26 & - & - & - & 26 & 54 & MN31998 \\
\hline Oxymycterus hispidus + & 8 & - & - & - & 8 & 54 & MN32005 \\
\hline Oxymycterus af. delator & - & - & 27 & - & 27 & 54 & MN46637 \\
\hline Delomys collinus + & 64 & - & - & - & 64 & 80 & MN31948 \\
\hline Nectomys squamipes & 3 & 21 & - & - & 24 & 56 & MN31973 \\
\hline Nectomys rattus & - & - & 13 & 23 & 36 & 52 & MN42974 \\
\hline Oligoryzomys flavescens & 23 & 4 & - & - & 27 & 64 & MN32164 \\
\hline Oligoryzomys fornesi & - & & - & 7 & 7 & 62 & CRB709 \\
\hline Oligoryzomys nigripes & 15 & 15 & - & - & 30 & 62 & MN32145 \\
\hline Oligoryzomys stramineus & - & - & - & 34 & 34 & 52 & MN46406 \\
\hline Oligoryzomys sp. $1 *$ & - & - & 12 & - & 12 & 70 & MN50307 \\
\hline Oligoryzomys sp. $2 *$ & - & - & 8 & - & 8 & 46 & MN50323 \\
\hline Oryzomys russatus + & 2 & - & - & - & 2 & 80 & MN31981 \\
\hline Oryzomys lamia* & - & - & 8 & - & 8 & 58 & MN46826 \\
\hline Oryzomys megacephalus & - & - & 11 & 25 & 36 & 54 & MN43009 \\
\hline Oryzomys angouya & 6 & - & - & - & 6 & 58 & MN32178 \\
\hline Oryzomys sp. (subflavus group) $*$ & - & - & 17 & - & 17 & 58 & MN61674 \\
\hline Oecomys sp. (group concolor) & - & - & - & 6 & 6 & 60 & CRB670 \\
\hline Pseudoryzomys simplex & - & - & 2 & - & 2 & 56 & CRB1127 \\
\hline Calomys expulsus & 1 & - & 7 & 11 & 19 & 66 & MN43033 \\
\hline Calomys tener & - & 2 & - & - & 2 & 66 & MN43035 \\
\hline Proechimys gratiosus + & 5 & - & - & - & 5 & & MN31978 \\
\hline
\end{tabular}


TABLE 1 (continued)

\begin{tabular}{|c|c|c|c|c|c|c|c|}
\hline Taxa & PNC & PD & PNCV & $\mathbf{T Z}$ & $\mathbf{T}$ & $2 n$ & $\begin{array}{l}\text { Voucher } \\
\text { specimens }\end{array}$ \\
\hline \multicolumn{8}{|l|}{ RODENTIA } \\
\hline Proechimys roberti & - & - & 34 & - & 34 & 30 & MN50195 \\
\hline Euryzygomatomys spinosus + & 2 & - & - & - & 2 & & MN32019 \\
\hline Thrichomys apereoides & - & - & 25 & 1 & 26 & 30 & MN50177 \\
\hline Cavia aperea & 1 & - & Av & - & 1 & & MN31980 \\
\hline Galea cf. flavidens * & - & - & 3 & - & 3 & & CRB1108 \\
\hline Myocastor coypus & - & 2 & - & - & 2 & 42 & MN46949 \\
\hline \multicolumn{8}{|l|}{ MARSUPIALIA } \\
\hline Didelphis albiventris & - & 6 & 1 & 3 & 10 & & MN43055 \\
\hline Didelphis aurita + & 2 & 18 & - & - & 20 & & MN43055 \\
\hline Gracilinanus agilis & - & - & 20 & 4 & 24 & & MN46510 \\
\hline Gracilinanus microtarsus + & - & 1 & - & - & 1 & & MN42981 \\
\hline Lutreolina crassicaudata & & 15 & & & 15 & & MN46509 \\
\hline \multicolumn{8}{|l|}{ RODENTIA } \\
\hline Marmosops incanus & 19 & - & - & - & 19 & & MN31927 \\
\hline Micoureus demerarae & - & - & 6 & 6 & 12 & & MN46554 \\
\hline Monodelphis domestica & - & - & 23 & 5 & 28 & & MN46585 \\
\hline Monodelphis umbristriata $*$ & - & - & 1 & - & 1 & & MN46570 \\
\hline Monodelphis sorex & - & 1 & - & - & 1 & & MN46571 \\
\hline Monodelphis touan + & 2 & - & - & - & 2 & & MN32166 \\
\hline Philander frenata & 13 & - & - & - & 13 & & MN32023 \\
\hline Thylamys velutinus & - & - & 1 & - & 1 & & CRB1075 \\
\hline \multicolumn{8}{|l|}{ LAGOMORPHA } \\
\hline Silvilagus brasiliensis & - & - & Av & 1 & 1 & & MN43004 \\
\hline Number of specimens & 372 & 142 & 239 & 130 & 886 & & \\
\hline Number of species & 21 & 13 & 21 & 14 & & & \\
\hline Trap-night & 3231 & 1830 & 2665 & 1440 & 9166 & & \\
\hline
\end{tabular}

Table 1 shows the distribution of traps-nights among the sampled areas, and Table 2 shows the number of traps-nights in each vegetation types. Whenever possible, all rodent specimens were karyotyped. Chromosome preparations were obtained from bone marrow cultured for two hours in RPMI 1640 with $20 \%$ foetal calf serum, ethidium bromide $(5 \mu \mathrm{g} / \mathrm{ml})$ and colchicine $\left(10^{-6} \mathrm{M}\right)$. Diversity was calculated using a Shannon index (Zar, 1996).

\section{Species identification}

We followed Wilson \& Reeder (1993) for species identification except for the following groups. For Oryzomys species we have followed the taxonomic criterion of Musser et al. (1998) except for O. lamia herein considered valid species (Bonvicino et al., 1998). For Oxymycterus species we have followed Oliveira (1998). For Akodon and Brucepattersonius species we have followed Hershkovitz (1998). 
TABLE 2

Number of specimens collected in each vegetation type. MF (mountain field), HM (humid mountain forest), MS (mountain scrub), PF (primary forest), SF (secondary forest), AP (vestigial forest, CU (wet grasslands), VE (vereda), CE (cerrado sensu stricto), CC (campo cerrado), CR (cerrado rupestre), GF (different types of gallery forest), HF (hillside forest), SD (semi deciduous forest), CA (very disturbed vegetation), AP (antropic vegetation), EU (eucalyptus plantation with native undergrowth).

\begin{tabular}{|c|c|c|c|c|c|c|c|c|c|c|c|c|c|c|c|c|c|}
\hline \multicolumn{8}{|c|}{ Atlantic Forest } & & \multicolumn{9}{|c|}{ Cerrado } \\
\hline MF & MS & HM & PF & SF & $\mathrm{CA}$ & AP & $\mathbf{E U}$ & Species & AP & GF & HF & SD & $\mathrm{CE}$ & $\mathrm{CC}$ & CR & $\mathrm{CU}$ & VE \\
\hline & & & & & & 3 & & R. rattus & & 3 & & & & & & & \\
\hline & & & 4 & 44 & & & & A. cursor & & & & & & & & & \\
\hline & & & & 14 & 14 & 1 & 1 & A. montensis & & & & & & & & & \\
\hline 1 & 41 & 17 & & 23 & & 1 & & A. serrensis & & & & & & & & & \\
\hline 4 & 13 & & & & & & & A. mystax & & & & & & & & & \\
\hline 1 & 5 & & 1 & 7 & & & & T. nigrita & & & & & & & & & \\
\hline & & & & 1 & 4 & 19 & & B. lasiurus & & & & & 2 & & 3 & 14 & 5 \\
\hline & 11 & 6 & & 1 & & & & B. griserufescens & & & & & & & & & \\
\hline & 22 & 4 & & & & & & O. caparaoe & & & & & & & & & \\
\hline & & & 2 & 5 & & 1 & & O. hispidus & & & & & & & & & \\
\hline & & & & & & & & O. af. delator & & & & & & & & 3 & 24 \\
\hline & 42 & 16 & & 6 & & & & D. collinus & & & & & & & & & \\
\hline & & & & 12 & 6 & 6 & & N. squamipes & & & & & & & & & \\
\hline & & & & & & & & N. rattus & & 34 & & & & & & & 2 \\
\hline & 23 & & & 2 & & 2 & & O. flavescens & & & & & & & & & \\
\hline & & & & & & & & O.fornesi & & 6 & & 1 & & & & & \\
\hline & 8 & & & 15 & 4 & 3 & & O. nigripes & & & & & & & & & \\
\hline & & & & & & & & O. stramineus & & 34 & & & & & & & \\
\hline & & & & & & & & Oligoryzomys sp.1 & & 2 & 2 & & 4 & & 2 & 2 & \\
\hline & & & & & & & & Oligoryzomys sp.2 & & & & & & & 7 & 1 & \\
\hline & & & & & & & & Oecomys sp. & & 6 & & & & & & & \\
\hline & & & 2 & & & & & O. russatus & & & & & & & & & \\
\hline & & & & & & & & O. lamia & & 2 & 4 & & 1 & & & 1 & \\
\hline & & & & & & & & O. megacephalus & & 34 & 2 & & & & & & \\
\hline & & & & 5 & & 1 & & O. angouya & & & & & & & & & \\
\hline & & & & & & & & Oryzomys sp. & & & & & 7 & 2 & 5 & 3 & \\
\hline & & & & & & & & P. simplex & & & & & & & & & 2 \\
\hline & 1 & & & & & & & C. expulsus & & 10 & & 2 & 2 & & 2 & 2 & \\
\hline & & & & & 2 & & & C. tener & & & & 2 & & & & & \\
\hline & & & & & & & & G. cf. flavidens & & & & & & & 3 & & \\
\hline & 1 & & & & & & & Cavia aperea & & & & & av & av & & & \\
\hline & & & & & & 2 & & M. coypus & & & & & & & & & \\
\hline & & & 2 & 3 & & & & P. gratiosus & & & & & & & & & \\
\hline & & & & & & & & P. roberti & & 30 & 1 & & 2 & & 1 & & \\
\hline
\end{tabular}


TABLE 2 (continued)

\begin{tabular}{|c|c|c|c|c|c|c|c|c|c|c|c|c|c|c|c|c|c|}
\hline \multicolumn{8}{|c|}{ Atlantic Forest } & & \multicolumn{9}{|c|}{ Cerrado } \\
\hline MF & MS & HM & PF & SF & CA & AP & $\mathbf{E U}$ & Species & $\mathbf{A P}$ & GF & HF & SD & CE & $\mathrm{CC}$ & CR & $\mathbf{C U}$ & VE \\
\hline & 1 & 1 & & & & & & E. spinosus & & & & & & & & & \\
\hline & & & & & & & & T. apereoides & & 1 & 3 & 1 & 3 & 1 & 16 & 1 & \\
\hline & & & & 3 & 1 & 2 & & D. albiventris & & 1 & & 2 & 1 & & & & \\
\hline & & & 2 & 9 & 3 & 6 & & D. aurita & & & & & & & & & \\
\hline & & & 1 & 10 & & 2 & & P. frenata & & & & & & & & & \\
\hline & & & & & & & & G. agilis & & & 7 & 4 & 11 & & & 1 & \\
\hline & & & & & 1 & & & G. microtarsus & & & & & & & & & \\
\hline & & & & 6 & & 9 & & L. crassicaudata & & & & & & & & & \\
\hline & 14 & & & 5 & & & & M. incanus & & & & & & & & & \\
\hline & & & & & & & & M. demerarae & & 9 & 1 & & 1 & & 1 & & \\
\hline & & & & & & & & M. domestica & & 3 & 6 & 5 & 5 & & 7 & 2 & \\
\hline & & & & & & & & M. umbristriata & & 1 & & & & & & & \\
\hline & & & & & & & 1 & M. sorex & & & & & & & & & \\
\hline & & & & 2 & & & & M. touan & & & & & & & & & \\
\hline & & & & & & & & T. velutinus & & 1 & & & & & & & \\
\hline & & & & & & & & S. brasiliensis & 1 & & & & & $\mathrm{Av}$ & & & \\
\hline 3 & 12 & 5 & 7 & 19 & 8 & 14 & 2 & N. species & 1 & 16 & 8 & 7 & 12 & 4 & 10 & 10 & 4 \\
\hline 6 & 182 & 44 & 14 & 173 & 35 & 58 & 2 & N. specimens & 1 & 177 & 26 & 17 & 39 & 3 & 47 & 30 & 33 \\
\hline 244 & 1209 & 237 & 312 & 2205 & 286 & 421 & 147 & Traps-night & 91 & 1823 & 84 & 232 & 482 & 208 & 509 & 373 & 303 \\
\hline
\end{tabular}

For Oligoryzomys species we have followed Bonvicino \& Weksler (1998). For Philander species we have followed Patton \& da Silva (1997). For Nectomys species we have followed Bonvicino (1994). For Monodelphis species we have followed Gomes (1991) and for Proechimys species we have followed Moojen (1948).

\section{RESULTS}

A sample of 887 specimens (50 species) was collected in the Atlantic Forest and/or Cerrado (see Table 1). The diploid number of each rodent species is shown in Table 1. Similar species richness but different species compositions were found between the parks and between the altered areas. The Cerrado biome presented a higher diversity in conserved areas $\left(\mathrm{H}^{\prime}=2.63\right.$ in PNCV against $\mathrm{H}^{\prime}=2.44$ in $\mathrm{PNC}$ ) and also in altered areas $\left(\mathrm{H}^{\prime}=2.16\right.$ in $\mathrm{TZ}$ against $\mathrm{H}^{\prime}=2.04$ in $\left.\mathrm{PD}\right)$.

According to the geographic distribution (widespread or restricted), frequency (common or rare), abundance, use of habitat (specialist or generalist) and presence in conserved and/or altered vegetation, species from both biomes were placed in different groups and sub-groups.

\section{Widespread species occurring in conserved and altered vegetation}

a. Common (easy to capture), abundant (with high number of captured specimens) and without restricted use of habitat: Akodon cursor, Akodon montensis, Bolomys lasiurus, Oryzomys megacephalus, Oligoryzomys nigripes, Didelphis aurita, Gracilinanus agilis, Monodelphis domestica, Thrichomys apereoides, Micoureus demerarae and Philander frenata. Cavia aperea is common and abundant, but difficult to capture. Akodon serrensis is common and abundant in the South of its distribution, however, in the Atlantic Forest of São Paulo and Rio de Janeiro states it is restricted to high altitudes. 
b. Common and restricted to habitats near streams: Nectomys rattus, Nectomys. squamipes, Lutreolina crassicaudata and Myocastor coypus. These species were abundant in some areas of their distribution.

c. Common but not abundant: Oligoryzomys flavescens, Oligoryzomys fornesi, Calomys expulsus, Calomys tener, Oryzomys russatus, Oryzomys angouya, Gracilinanus microtarsus, Marmosops incanus, Didelphis albiventris and Silvilagus brasiliensis.

d. Rare and not abundant: Thaptomys nigrita, Pseudoryzomys simplex, Eurizygomatomys spinosus and Monodelphis sorex. Thaptomys nigrita and Pseudoryzomys simplex appear to have a restricted habitat use, occurring in humid habitats such as wet grassland while the other two species were captured in altered vegetation.

\section{Species with restricted distribution occurring only in unaltered vegetation}

a. Rare species with restricted habitat use: Oxymycterus hispidus, Monodelphis touan, Galea cf. flavidens, Thylamys velutinus, Monodelphis umbristriata, Oryzomys lamia and Oligoryzomys sp.2. These rare species were habitat specialists with discrete altitudinal distribution.

b. Abundant species with restricted habitat use: Oxymycterus caparaoe, Oxymycterus af. delator, Delomys collinus, Brucepattersonius griserufescens, Akodon mystax, Proechimys gratiosus, Proechimys roberti, Oryzomys sp. (subflavus group) and Oligoryzomys sp.1.

The Cerrado small mammals can also be divided into different groups according to their use of the habitat.

\section{Gallery forest inhabitants}

a. Species with ability to use all gallery forest types, including degraded ones. In this category we can place the majority of nonendemic Cerrado small mammals.

b. Specific gallery forest inhabitants found only in less altered areas of substantial size: $O$. lamia and $P$. roberti, this latter, contrary to $O$. lamia can be locally abundant.
2. Wet grasslands and other open wetland physiognomy inhabitants ("vereda", wet grassland and marsh): O. af. delator.

3. Rock strewn savannah ("cerrado rupestre") inhabitants: G. cf. flavidens, Oligoryzomys sp.2 and T. apereoides. T. apereoides was basically captured in "cerrado rupestre" although it can also occur in other physiognomies. This species is of limited interest as an indicator, since it can live in degraded habitats. Oligoryzomys sp. 2 is a habitat specialist limited to high altitudes in Cerrado and $G$. cf. flavidens is rare and difficult to capture.

4. Open vegetation physiognomy inhabitants includes $P$. simplex (a widespread species), Oligoryzomys sp.1 and Oryzomys sp. (subflavus group). The last two species are new species and there is little information about its ecological requirements. $P$. simplex is rarely collected.

5. Specific inhabitants of high altitude vegetation of the Atlantic Forest: D. collinus, A. mystax, B. griserufescens and O. caparaoe.

\section{DISCUSSION}

Similar species richness but different species compositions were found in the conserved areas of the Atlantic Forest and Cerrado. These results were also found in respect to altered areas. However, the Cerrado biome presented diversity higher than the Atlantic Forest in conserved areas $\left(\mathrm{H}^{\prime}=2.63\right.$ and 2.44 respectively). Higher diversity in the Cerrado was also found when comparing the altered areas $\left(H^{\prime}=2.16\right.$ and 2.04 respectively). These results differ from the present consensus of a more diverse fauna in Atlantic Forest, suggesting that these biomes are similar in respect to the species richness, despite being slighty different in respect to diversity.

The different ecological categories attributed to the set of small mammal fauna studied suggest the potential use of these taxa as indicators of environmental quality. Some species can be considered ubiquitous (Group I) because they can be found in a wide geographical region and have the capacity to exploit altered vegetation and urban areas. These species have no value as indicators of the state of habitat alteration. Although some species restricted to anthropic habitats (e.g. Rattus rattus) could be useful as indicators of habitat 
degradation, they might also occur in conserved areas, as an example, Rattus rattus occurs in the PETAR semi-natural landscape (S. Lindbergh, personal observation). Other ubiquitous species despite having restricted habitat use (the semiaquatic species of Group Ib) also occur in conserved, altered and peri-domicile areas. The ubiquitous species that are not abundant or are rare (Group Ic and Id) but also occur in conserved and altered vegetation cannot be used as indicators. Species of Group I are not good indicators of conservation status but can be important for the evaluation of alpha and beta diversity.

Species with restricted distribution were in Group II. The rare species found in unaltered vegetation (Group IIa) are good indicators of environmental quality, despite being rare. They can be helpful in conservation unit management planning and for the determination of suitable boundaries. Abundant species with restricted habitat use (Group IIb) are easier to capture and are valuable tools to access environmental quality as well as how it changes.

The Cerrado small mammal species inhabitants of non-specific gallery forest (Group 1a) due to their plasticity are not useful as indicators. At the Cerrado of Central Brazil in the end of dry seasons, species that normally are found in open vegetation formation can also be found in gallery forests (Bonvicino et al., 1997). On the other hand, the species inhabitants of preserved gallery forest of substantial size (Group 1b, see Bonvicino \& Weksler, 1998) are good indicators of the state of degradation of the vegetation. Today, due to high rates of natural habitat destruction, these species are difficult to collect. Extensive gallery forests are characteristic of Cerrado forest formations in lower altitudes and are the first to be cleared. The vulnerability of these specialised species habitats deserve special attention.

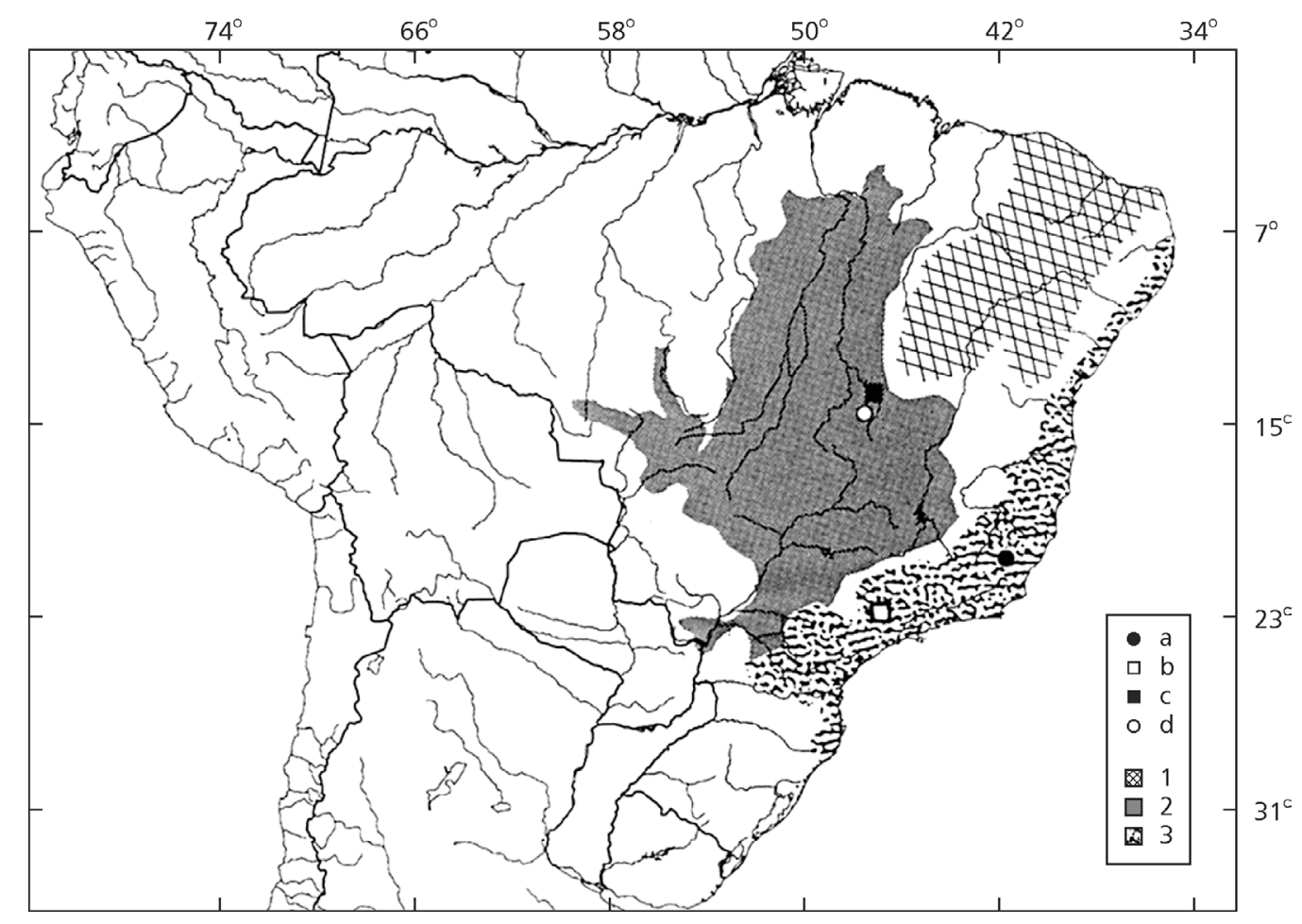

Fig. 1 - Collecting localities: (a) Caparaó National Park, (b) Pedreira, (c) Teresina de Goiás, (d) Chapada dos Veadeiros National Park, and the limit of (1) Caatinga, (2) Cerrado and (3) Atlantic Forest biomes. 
The open vegetation formations are the most abundant phyto-physiognomies in the Cerrado of Central Brazil. Inhabitants of wet grasslands and other open wetland physiognomies are useful as environmental indicators (Group 2) since they are either less abundant or absent in degraded vegetation.

Open savannah physiognomy inhabitants (Group 4) are adapted to degraded wood formations when part of their habitat is still present, and are of limited use as environmental indicators. In the Atlantic Forest the differences among vegetation types are not so clear as in the Cerrado biome. However at high altitude the differentiation is greater and each vegetation type has its associated fauna. This specific vegetation inhabitants of the Atlantic Forest (Group 5) have restricted distribution and can be found only at high altitudes but are abundant in conserved vegetation, serving as good indicators of the state of conservation.

To have a general idea of the state of conservation of an area a group of species should be used instead of a single one. Alone, each species of Group Ia has limited value as indicator, however a sample containing only species of this group indicates a disturbed area, whereas Group Ia species together with Group II indicates another situation. The use of a group of species can furnish more detailed ideas about the tenuous variation found in the different habitats that compose the sampled area. This is more evident in the Cerrado vegetation where more than 30 physiognomies were described (Eiten, 1994), but it also applies to the Atlantic Forest where different vegetation types are also present, although with less differentiation. Collecting rodents and marsupials can furnish considerable data in a short time, which among mammals can only be compared with data from bats collection and other colonial species. But, unlike bats and other colonial species, the impact of collecting on these populations is, in most of the cases, negligible. And again unlike bats, rodents and marsupials are not highly mobile showing a higher endemicity as well as a higher variance in species turnover. These characteristics make rodents and marsupials one of the fittest indicators for environmental impact evaluation and monitoring.
The endemicity of species is a good tool to determine protected areas. In the Cerrado of Central Brazil species can be endemic with a restricted distribution like $M$. umbristriata (Gomes, 1991), O. lamia (Bonvicino et al., 1998), Oryzomys sp. (subflavus group, Bonvicino et al., 1999), G. cf. flavidens, Oligoryzomys sp.1 and Oligoryzomys sp.2, all of these species are under protection in at least one conservation area. Endemic Brazilian Cerrado small rodents with restricted distribution are being found with increasing regularity: Juscelinomys candango (Brasília, DF; Moojen, 1965), Microakodontomys transitorus (Parque Nacional de Brasília, DF; Hershkovitz, 1993), Thalpomys cerradensis (Brasília, Federal District; Baliza, Goiás State and Jaborandi, Bahia State), Oryzomys sp. (subflavus group; Bonvicino et al., 1999). Other rodent species are restricted to the Brazilian Cerrado and Caatinga biomes like Oligoryzomys stramineus, Wiedomys pyrrhorhinos, Kerodon rupestris and Kerodon acrobata. These findings contradict the view of Cerrado fauna as a composition of Atlantic and Amazonian forest faunas (Fonseca \& Redford, 1984). Despite containing elements of Amazonian fauna in the North and elements of Atlantic Forest in the South of the Cerrado biome, it also has an endemic fauna of open biomes (e.g. Cerrado and Caatinga), and a fauna restricted to the Cerrado biome. Among the Atlantic Forest species studied P. gratiosus, D. collinus, T. nigrita, A. serrensis, A. mystax, $O$. caparaoe, $O$. hispidus, and B. griserufescens are endemic and, again all of them are under protection in at least one conservation area. The rich presence of endemic species in this biome has never been questioned (Voss, 1993).

In both biomes endemic species were captured only in the conservation units; certainly a clear illustration of the conservation unit value for the biodiversity preservation and maintenance, as well as the potential of these animals to be environmental indicators. They can serve both to identify areas of high biodiversity interest and, through their distribution, to set coherent boundaries for the present or future conservation units. 
Acknowledgments - This work was supported by IBAMA (Instituto Brasileiro do Meio Ambiente e dos Recursos Naturais Renováveis), FIOCRUZ (Fundação Instituto Oswaldo Cruz, Depto. Medicina Tropical), Museu Nacional (Rio de Janeiro), and CNPq (Conselho Nacional de Desenvolvimento Científico e Tecnológico)/PRONEX. We are very grateful for support received from the director of Caparaó and Chapada dos Veadeiros National Parks, and other park personal. B. Brown, S. M. Franco, A. A. Sodré, A. Persequillo, A. C. de Paula, J. Freitas, M. Weksler, B. Lemos, V. Penna-Firme and P. S. D'Andrea helped in the field. Sampling in PNC was authorised by IBAMA-DEVIS (special license number 046/92), research in a National Park by IBAMA-DEUC (license number 22/92). Sampling in PNCV was authorised by IBAMA-DEVIS, research in a National Park by IBAMA-DEUC (license number 052/96).

\section{REFERENCES}

BONVICINO, C. R., 1994, Especiação do rato d'água Nectomys. Abordagem cariológica, morfológica $e$ geográfica. Unpublished Ph.D. Thesis, Universidade Federal do Rio de Janeiro, Brazil.

BONVICINO, C. R., FREITAS, S. R. \& D'ANDREA, P. S., 1997, Influence of bordering vegetation, width and state of conservation of a gallery forest on the presence of small mammals. In: L. L. Leila \& C. H. Saito (eds.), Contribuição ao conhecimento ecológico do Cerrado. Editora UnB, Brasília.

BONVICINO, C. R., OTAZU, I. B. \& WEKSLER, M., 1998, Oryzomys lamia Thomas, 1901 (Rodentia, Sigmodontinae): karyotype, geographic distribution and conservation status. Mammalia, 62: 253-258.

BONVICINO, C. R. \& WEKSLER, M., 1998, A new species of Oligoryzomys (Rodentia, Sigmodontinae) from Northeastern and Central Brazil. Z. Säuget., 63: 90-103.

BONVICINO, C. R., OTAZU, I. B. \& BORODIN, P. M., 1999, Chromosome variation in Oryzomys subflavus species group (Sigmodontinae, Rodentia) and its taxonomic implication. Cytologia, 64: 327-332.

CARLETON, M. D. \& MUSSER, G. G., 1989, Systematics studies of Oryzomyine rodents (Muridae, Sigmodontinae): a synopsis of Microryzomys. Bul. Amer. Mus. Nat. Hist., 191: 1-83.

EITEN, G., 1994, Vegetação do Cerrado. In: M. N. Pinto (ed.), Cerrado. Sematec/Editora UnB, Brasília.

FONSECA, G. \& REDFORD, K., 1984, The mammals of IBGE Ecological reserve, Brasília, and the analysis of the role of gallery forest in increasing diversity. Rev. Brasil. Biol., 44: 517-523.

GOMES, N. F., 1991, Revisão sistemática do gênero Monodelphis (Didelphidae: Marsupialia). Unpublished Ms Dissertation, Universidade Estadual de São Paulo, Brazil.

HERSHKOVITZ, P., 1990, The Brazilian rodents genus Thalpomys (Sigmodontinae, Cricetidae) with description of a new species. J. Nat. Hist., 24: 763-783.
HERSHKOVITZ, P., 1993, A new Central Brazilian genus and species of sigmodontine rodent (Sigmodontinae) transitional between akodonts and oryzomyines, with a discussion of muroid molar morphology and evolution. Field. Zool. n. s., 75: 1-18.

HERSHKOVITZ, P., 1994, The description of a new species of South American hocicudo or long-nose mouse, genus Oxymycterus (Sigmodontinae, Muroidea), with critical review of the generic content. Fiel. Zool. n. s., 79: 1-43.

HERSHKOVITZ, P., 1998, Report of some sigmodontinae rodents collected in southeastern Brazil with description of a new genus and six new species. Bonn. Zool. Beitr., 47: $193-256$.

MARINHO-FILHO, J., REIS, M. L., DE OLIVEIRA, P. S., VIEIRA, E. M. \& PAES, M. N., 1994, Diversity standards and mammal numbers: conservation of the Cerrado Biodiversity. Anais Acad. Brasil. Ciênc., 66 (supl.1): 149-156.

MOOJEN, J., 1948, Speciation in the Brazilian spiny rats (genus Proechimys, family Echimyidae). Univ. Kansas Publ., 1: 301-406.

MOOJEN, J., 1965, Novo gênero de Cricetidae do Brasil Central (Glires, Mammalia). Rev. Brasil. Biol., 25: 281-285.

MOOJEN, J., LOCKS, M. \& LANGGUTH, A., 1997, A new species of Kerodon Cuvier, 1825 from Goiás, Brazil (Mammalia, Rodentia, Caviidae). Bol. Mus. Nac. n. s., Zoologia, Rio de Janeiro, 377: 1-10.

MUSSER, G. G., CARLETON, M. D., BROTHERS, E. M. \& GARDNER, A. L., 1998, Systematic studies of oryzomyine rodents (Muridae, Sigmodontinae): diagnoses and distributions of species formerly assigned to "Oryzomys capito". Bul. Amer. Mus. Nat. Hist., 236: 1-376.

OLIVEIRA, J. A., 1998, Morphometric assessment of species groups in the South American rodent genus Oxymycterus. Ph.D. Thesis, Texas Tech University, Lubbock, Texas.

PALMA, R. E. \& YATES, T. L., 1998, Phylogeny of southern South America mouse opossums (Thylamys, Didelphidae) based on allozyme and chromosomal data. Z. Säuget., 63: $1-15$.

PATTON, J. L. \& DA SILVA, M. N. F., 1997, Definition of species of pouched four - eyed opossum (Didelphidae, Philander). J. Mamm., 78: 90-102.

VOSS, R. S., 1993, A revision of the Brazilian muroid rodent genus Delomys with remarks on "Thomasomyine" characters. Am. Mus. Novit., 3073: 1-44.

WEKSLER, M., GEISE, L. \& CERQUEIRA, R., 1999, A new species of Oryzomys (Rodentia, Sigmodontinae) from Southwest Brazil, with comments on the classification of the O. capito species group. Zool. J. Linn. Soc., 125: 445-462.

WILSON, D. E. \& REEDER, D. M., 1993, Mammals species of the world. A taxonomic and geographic reference. 2. ed. Smithsonian Institution Press, Washington, D.C.

ZAR, J. H., 1996, Bioestatistical Analisys. 3. ed. PrenticeHall, Inc., Englewood Cliff, NJ. USA. 